\title{
O falar raiano de Marvão / Valencia de Alcántara - uma variedade linguística em perigo
}

\section{The Border Dialect of Marvão / Valencia de Alcántara - an Endangered Linguistic Variety}

\author{
Teresa Simão [tssimao@live.com.pt] \\ Centro Interdisciplinar de História, Culturas e Sociedades, Universidade de Évora, Portugal
}

\section{RESUMO}

Na região de Marvão / Valencia de Alcántara, a fronteira linguística não corresponde à geopolítica, daí que uma variedade do Português usada no Nordeste do Alentejo se tenha expandido para Espanha e caracterizado uma zona considerável do território de Valencia de Alcántara. Integrado nos dialetos portugueses centro-meridionais, na variedade da Beira Baixa e Alto Alentejo, partilha a maior parte das suas características, todavia, demarca-se dos falares dos concelhos circundantes por algumas particularidades nos domínios fonético-fonológico e léxico-semântico. Como esta variedade linguística se encontra vulnerável em território português e está seriamente em perigo em território espanhol, é urgente que se deem passos concretos com vista à sua revitalização. O presente artigo pretende dar a conhecer o panorama linguístico da região, apresentar as principais características fonético-fonológicas, morfossintáticas e léxico-semânticas deste falar raiano, bem como apontar alguns caminhos para inverter a tendência de desaparecimento.

\section{Palavras-Chave}

Falar de raia; Marvão; Valencia de Alcántara; variedade linguística ameaçada; património cultural imaterial

\begin{abstract}
The linguistic border in Marvão / Valencia de Alcántara does not correspond to the geopolitical border between Portugal and Spain. This is explained by the fact that a Portuguese linguistic variety used in the Northeast part of Alentejo expanded to Spain and characterizes a large region in Valencia de Alcántara. The variety of Marvão / Valencia de Alcántara belongs to the Southern Centre Portuguese dialects (Beira Baixa and Alto Alentejo), and therefore shares their main characteristics. However, it differs from the varieties spoken in the surrounding villages due to some particularities at both phonetical-phonological and lexical-semantic levels. As this linguistic variety is vulnerable in Portugal and it is seriously endangered in the Spanish territory, it is urgent to implement some measures to reverse the situation and contribute to its revitalization. This paper aims to describe the linguistic situation of the region, to present the main phonetical-phonological, morphosyntactic and lexical-semantic features of this border dialect, and to show some possible strategies to reverse the disappearance trend that the variety of Marvão/Valencia de Alcántara is facing.
\end{abstract}




\section{KEYWORDS}

Border dialect; Marvão; Valencia de Alcántara; endangered linguistic variety; intangible cultural heritage

RECEBIDO 2019-10-31; ACEITE 2020-03-19

\section{Introdução}

O presente artigo pretende dar conta do panorama linguístico atual na raia de Marvão/ Valencia de Alcántara.

Desde 2003 que nos dedicamos ao estudo deste falar, inicialmente apenas em solo português e posteriormente também em território espanhol. Ao longo destes anos, mais do que sistematizar as suas características fonético-fonológicas, morfossintáticas e léxico-semânticas, tem sido possível estudar a evolução desta variedade linguística, a variação do seu uso entre os diversos falantes, bem como em diferentes situações de comunicação e chegar a algumas conclusões, que aqui apresentaremos.

Com vista à sistematização e divulgação deste falar raiano já foram dados alguns passos, mas muito há ainda por fazer para que continue a ser passado às novas gerações e mantenha a sua vitalidade, atualmente em perigo.

\section{Breve caracterização do território}

\subsection{O concelho de Marvão}

Do ponto de vista geográfico, Marvão fica localizado no Nordeste do Alentejo, no distrito de Portalegre, em Portugal, e tem como limites, a norte/este, o rio Sever (que delimita a fronteira entre Portugal e Espanha), a sul, o concelho de Portalegre e, a oeste, o concelho de Castelo de Vide.

Habitado desde o Paleolítico, apenas os sítios de permanência humana foram variando ${ }^{1}$. No período da romanização, muitos são os locais que atestam a presença dessa civilização na zona norte do concelho, mas foi a sul que fundaram a cidade de Ammaia, que chegou a assumir o estatuto de municipium. Com a chegada dos bárbaros e a desagregação do Império Romano do Ocidente, esta cidade também sucumbe e a população vai escolher locais mais abrigados para viver, sobretudo na região norte. A chegada dos árabes deu origem a novo repovoamento e à procura da fortaleza natural de Marvão para refúgio. Por volta de 876/77, o muladi Ibn Maruán terá escolhido o inóspito morro de Marvão² para se refugiar e construir uma fortaleza

1 Na redação deste breve resumo sobre a evolução do povoamento de Marvão, tivemos por base a Nova Carta Arqueológica do Concelho de Marvão, publicada como número especial da revista Ibn Maruán no 14, em 2007.

2 Para uma melhor compreensão da origem do topónimo Marvão, recomendamos a leitura do subcapítulo 2.1. “Origens do topónimo Marvão", presente em Simão 2011: 55-58. Entre as várias versões aí presentes, destacamos a de Adel Sidarus, publicada em Sidarus, A. (1991). Amaia de Ibn Maruán: Marvão. Ibn Maruán - Revista Cultural do Concelho de Marvão, n 1, 13-26. 


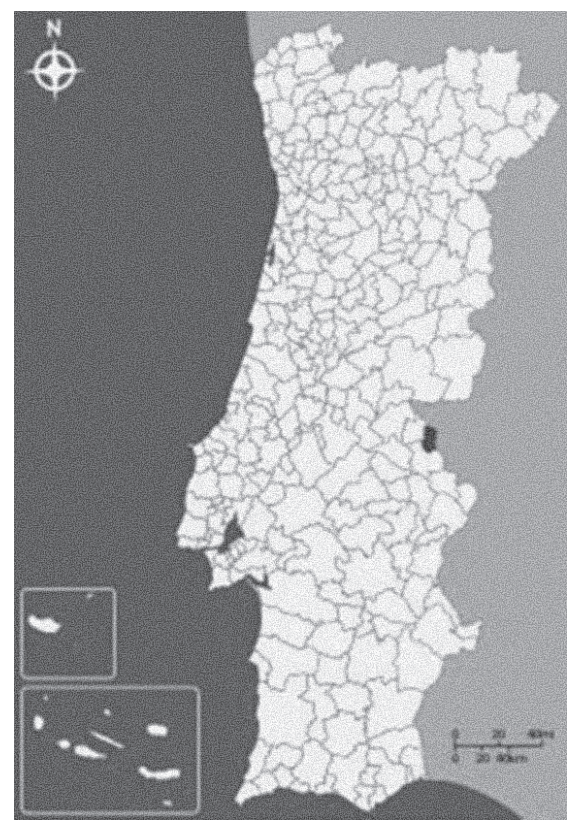

Ilustração 1: Mapa que evidencia a localização de Marvão no contexto português

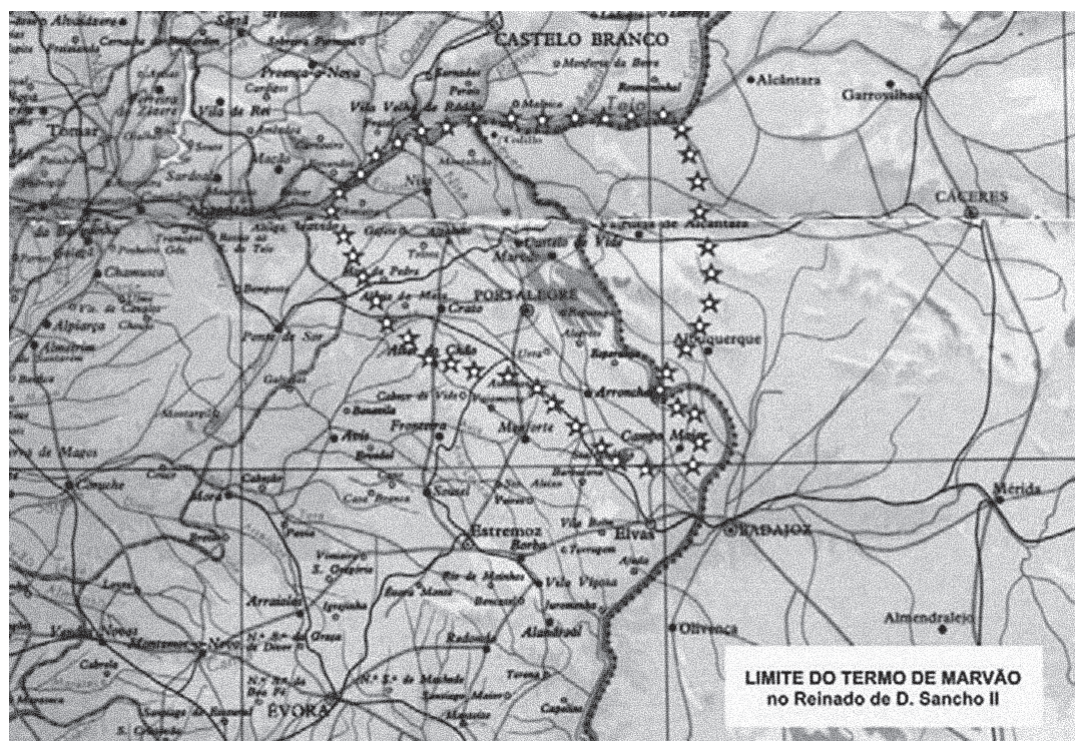

Ilustração 2: Limite do termo de Marvão em 1226 


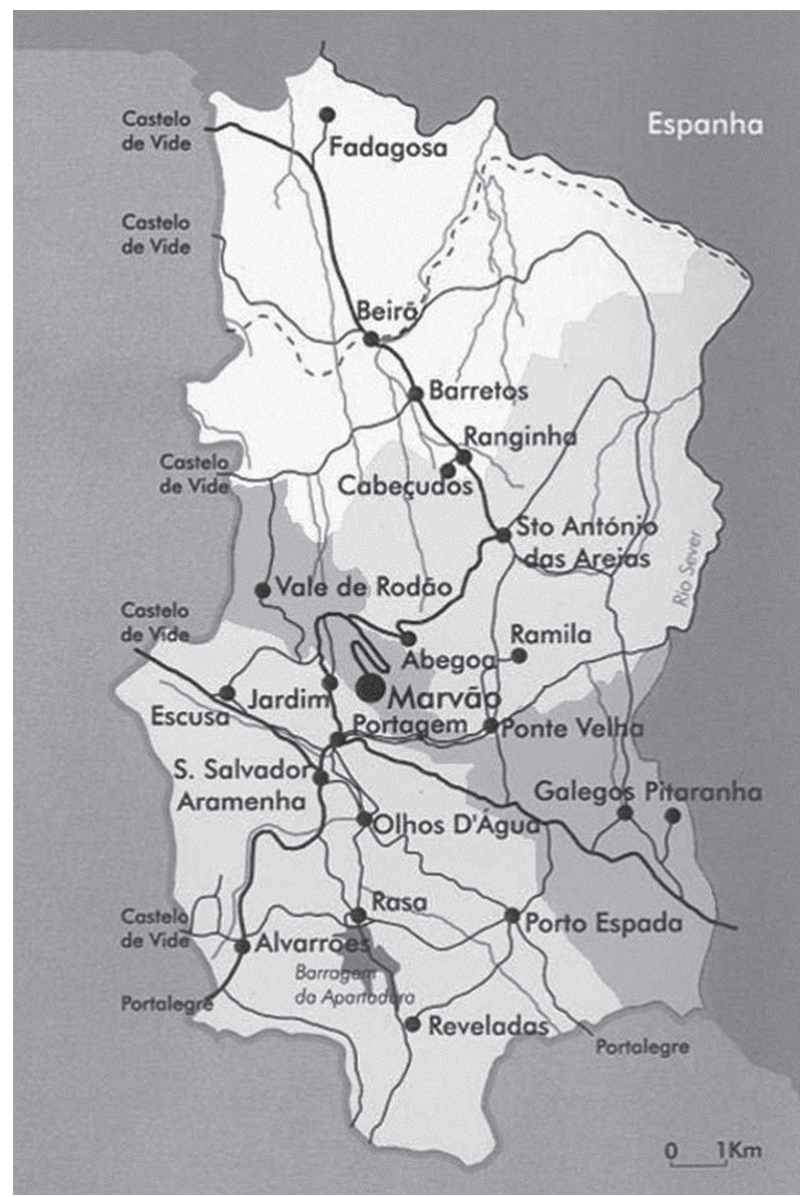

Ilustração 3: Mapa das quatro freguesias do concelho de Marvão

que, desde essa altura até à primeira metade do século XIX, sempre funcionou como um ponto estratégico de defesa relativamente aos diversos inimigos que por lá passaram. No período da Reconquista Cristã, Marvão terá sido conquistado entre 1160 e 1166, por D. Afonso Henriques, e terá recebido a sua primeira carta de foral em 1226, no reinado de D. Sancho II. Nessa altura, o seu território abrangia grande parte do distrito de Portalegre e uma zona do atual território de Valencia de Alcántara, mas entretanto foi sendo reduzido ${ }^{3}$. Localizada na linha de fronteira e com uma importante fortaleza de defesa, esta região foi recorrentemente palco de episódios bélicos, o que gerou uma grande instabilidade na população.

Atualmente o concelho tem uma área de $154,9 \mathrm{~km}^{2}$, distribuída por quatro freguesias, nomeadamente, Beirã e Santo António das Areias, a norte, Santa Maria de Marvão e São Salvador da Aramenha, a sul, e apresenta uma densidade populacional muito baixa $-20,33$ habitantes $/ \mathrm{km}^{2}$. 


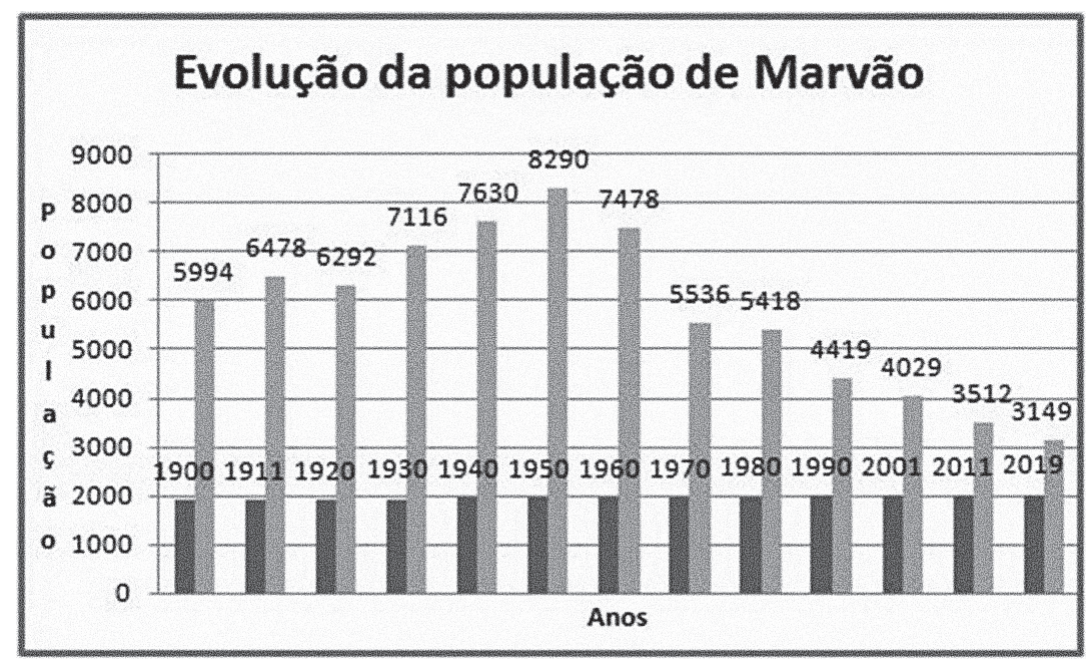

Ilustração 4: Gráfico da evolução da população de Marvão, séc. XX e XXI

(Dados recolhidos em www.ine.pt e PORDATA.)

Só depois de terminados os episódios bélicos a população se pode fixar mais descansadamente e, como se pode verificar no gráfico, foi aumentando até à década de 50 do século passado. Desde então, iniciou-se uma recessão demográfica que cada vez se acentua mais.

Segundo dados de 2019 obtidos no PORDATA, Marvão tem cerca de 3149 habitantes. Nas últimas décadas, a quebra na natalidade e a falta de ofertas de emprego que fixem os habitantes têm conduzido à desertificação do território e ao acentuado envelhecimento da sua população. Este panorama justifica a atual taxa de analfabetismo de $13,2 \%$, quando a média nacional é de 5,2\% .

\subsection{O território de Valencia de Alcántara ${ }^{5}$}

O município de Valencia de Alcántara fica localizado no extremo mais ocidental da Extremadura espanhola e integra a província de Cáceres, ficando o principal núcleo urbano a $14 \mathrm{~km}$ da fronteira com Portugal e a $87 \mathrm{~km}$ de Cáceres. Este município faz fronteira com Portugal a oeste, com Herrera de Alcántara e Santiago de Alcántara a norte, com Membrío e Salorino a este e com San Vicente de Alcántara a sul.

A cidade de Valencia de Alcántara constitui o núcleo urbano principal, estando o resto da população distribuída pela chamada "Campiña", constituída por dez aldeias, designadamente, El Pino, Las Huertas de Cansa, San Pedro de los Majarretes, Las Casiñas, Aceña de la Borrega, Alcorneo, Las Lanchuelas, La Fontañera, Jola e La Miera, bem como outros pequenos aglomerados populacionais.

4 Dados dos Censos de 2011.

5 A informação contida no resumo sobre a evolução do povoamento de Valencia de Alcántara teve por base essencialmente a obra de Francisco Galavís Bueno. 


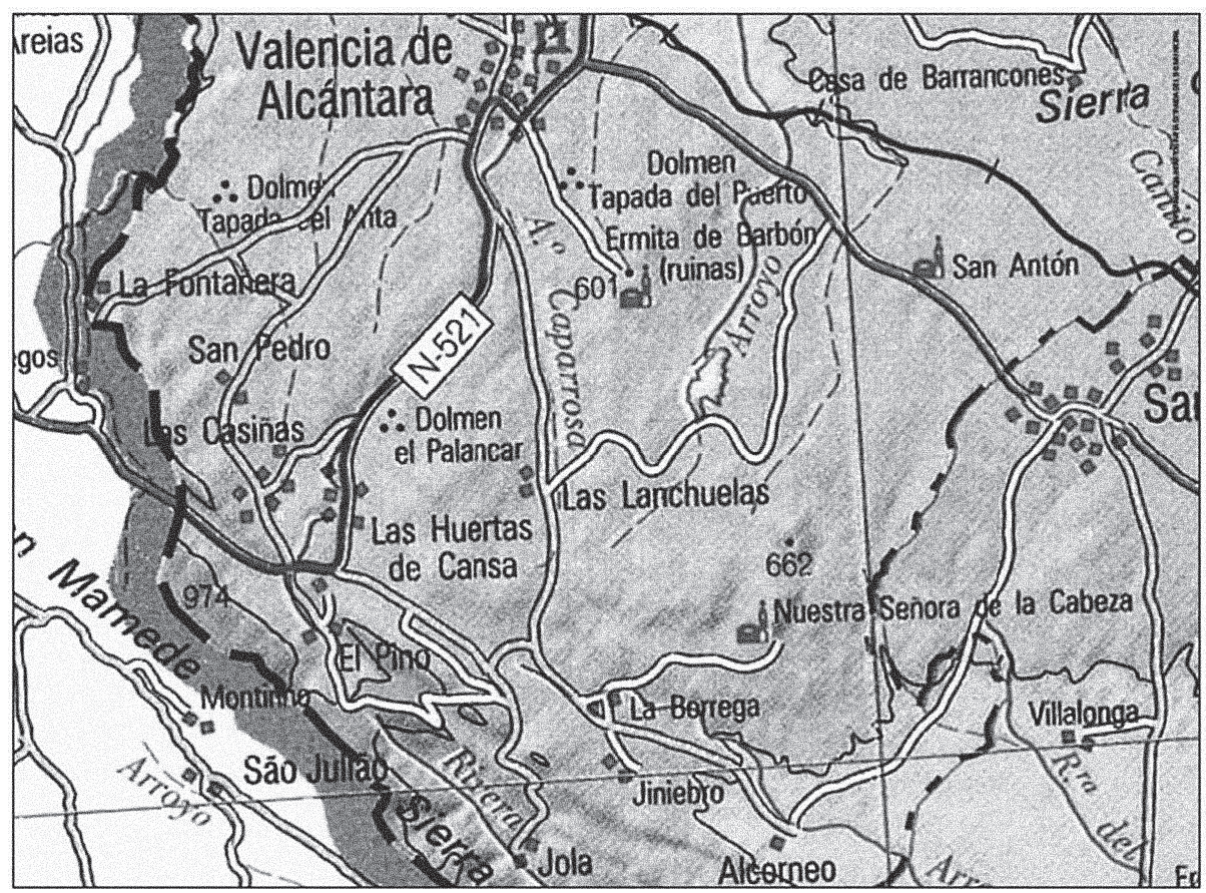

Ilustração 5: Pormenor do mapa de Valencia de Alcántara e da Campiña

À semelhança de Marvão, desde o Paleolítico que este território foi habitado, variando também os locais escolhidos em função das eras e dos conflitos militares. Desde a Idade Média que foi concebida como uma praça com funções militares e assim permaneceu quase até ao século XX. Em 876, quando Ibn Maruán construiu a sua fortaleza no concelho vizinho, apoderou-se das terras circundantes, estendendo-se essa abrangência às terras de Valencia. Como já referido, aquando da atribuição da carta de foral a Marvão, o território valenciano fazia parte do município português, passando depois a pertencer à Ordem de Alcántara ${ }^{6}$. Durante o início do século XVIII, foi pertença de Portugal por dez anos, retomando a independência em 1715 ${ }^{7}$. Cessadas as lutas com Portugal no início do século XIX e preparado o caminho para o desenvolvimento e a modernidade da região, eis que a primeira metade do século XX foi ainda marcada pela Guerra Civil (1936-1939) e por um longo período de ditadura (1939 a 1976), que muito dificultaram a vida a todos os espanhóis.

Apesar de todo o clima de instabilidade, como se pode ver no gráfico que se segue, houve um aumento da população até à década de $40^{8}$. Desde então, tem-se assistido ao seu decréscimo, sendo atualmente a sua densidade demográfica de $9,13 \mathrm{hab} . / \mathrm{km}^{2}{ }^{9}{ }^{9}$

6 Galavís Bueno (2010: 87-97).

7 Galavís Bueno (2010: 34).

8 Dados recolhidos no Instituto Nacional de Estadística (ine.es) até 2010.

9 Dados de 2019 fornecidos pelo Ayuntamiento de Valencia de Alcántara. 


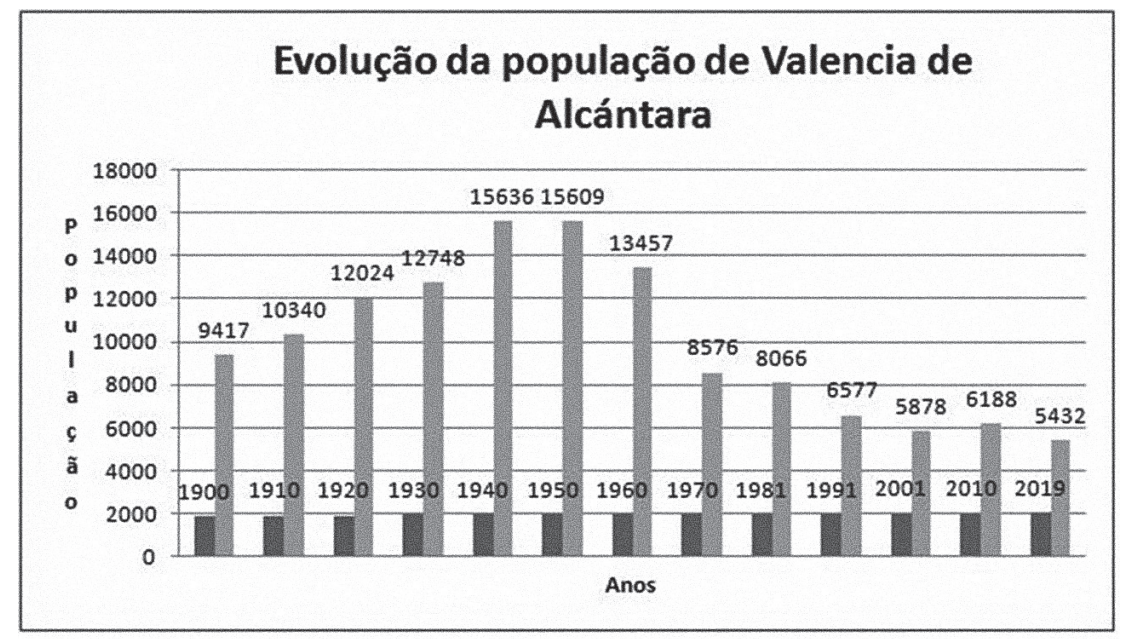

Ilustração 6: Evolução da população de Valencia de Alcántara, séc. XX e XXI

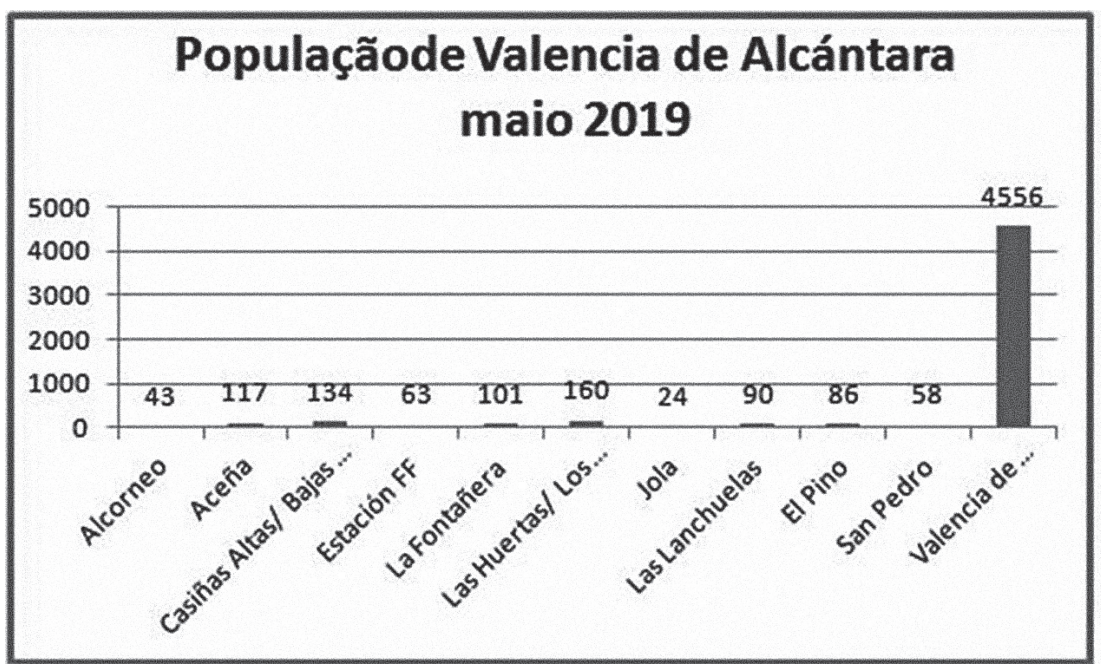

Ilustração 7: Gráfico da população de Valencia e da Campiña

Tal como o Alentejo, no século XX, mais concretamente nas décadas de 50, 60 e 70, a Extremadura conheceu um elevado fluxo migratório ${ }^{10}$. Os extremenhos rumaram sobretudo à Catalunha, Madrid e País Basco (dentro de Espanha), bem como Alemanha, França e Suíça (no estrangeiro $)^{11}$, onde procuraram melhores condições laborais. Entre 1961 e 1975, Valencia de Alcántara

10 Cayetano Rosado (2007: 22). 
perdeu 44,74\% dos seus habitantes ${ }^{12}$, verificando-se uma redução de 18 para 11 habitantes $/ \mathrm{km}^{2}$ La Campiña viu partir 51,63\% da sua população, passando de uma densidade demográfica de 31 para 17 habitantes $/ \mathrm{km}^{2}$. Motivada pela pobreza, pela falta de trabalho e de perspetivas de futuro, esta emigração gerou ainda mais dificuldades, pois estas regiões perderam o seu capital humano e tal contribuiu para um envelhecimento da população e um consequente subdesenvolvimento.

A tendência de despovoamento mantém-se e a Campiña vai estando cada vez mais desertificada, como se pode verificar no gráfico. De notar que os dados apresentados dizem respeito aos habitantes recenseados e muitos deles só regressam nas férias do verão. Na verdade, o número de residentes habituais é muito mais reduzido do que apresentam as estatísticas ${ }^{13}$.

Quanto à taxa de analfabetismo, nas últimas décadas, tem-se verificado uma redução grande. Em 2001, era de 8,9\%, em 2011, evoluiu para 2,78\%, sendo em 2019 de 0,8\%. Se do ponto de vista social estes dados são animadores, no que toca à manutenção do falar raiano, estamos perante um fator que muito contribui para o seu desaparecimento, uma vez que esta variedade dialetal se afasta da língua aprendida nas escolas e há uma tendência muito maior para a imposição da norma relativamente à variante minoritária e socialmente desconsiderada.

\subsection{As relações de fronteira}

A vivência numa região de fronteira e o convívio estreito entre as populações dos dois lados da raia sempre proporcionaram um estilo de vida e uma cultura muito peculiares.

No caso de Marvão e Valencia de Alcántara, até as características geográficas contribuem para a indefinição da fronteira, pois há uma continuidade paisagística e geomorfológica ${ }^{14}$.

Segundo Jorge de Oliveira ${ }^{15}$, as relações de proximidade entre as gentes dos dois territórios recuam à Pré-história, sendo o rio Sever sempre um fator de união determinante. Durante o período romano, essa proximidade manteve-se, até porque o município de Ammaia englobava um amplo território que também abrangia Valencia e nele surgiu uma vasta rede de vias de comunicação que aproximou ainda mais as localidades que o constituíam. No período do domínio islâmico, teve lugar novo reforço, especialmente no século IX, com a ação de Ibn Maruán.

Definida a linha de fronteira entre Portugal e Castela, com a assinatura do Tratado de Alcanizes (1297), a 12 de dezembro de 1313, foi assinado, pelos representantes de D. Dinis e da Ordem de Alcântara, o “Tratado de Colaboração entre Marvão e Valencia de Alcántara”. Este foi um documento de acordo entre localidades e representa o reconhecimento, por parte dos poderes centrais, de que havia uma vivência comum para além de uma fronteira política. Significou uma tentativa de resolver algumas contendas e visou também estabelecer como é que os habitantes das duas localidades podiam ter acesso às riquezas de um lado e do outro sem pagar quaisquer impostos.

12 Cayetano Rosado (2007: 33).

13 Dados fornecidos pelo Ayuntamiento de Valencia de Alcántara.

14 Medina García (2009: 131).

15 Numa comunicação subordinada ao tema "Marvão e Valência de Alcântara: Uma raia sem fronteiras - o Tratado de 1313”, apresentada em Marvão, por ocasião da comemoração dos 700 anos do referido tratado. 
Também os muitos casamentos testemunham as estreitas relações entre as gentes dos dois lados da fronteira. Esta proximidade proporcionou a partilha das culturas dos dois países e a construção de uma cultura comum, a da raia. Para os encontros amorosos, muito terão contribuído os diversos comércios e salões de baile existentes na região. As localidades portuguesas estavam mais próximas da maioria das povoações da Campiña do que a cidade de Valencia de Alcántara, sendo mais usual os espanhóis irem a Portugal do que à sede do seu município.

A relação estreita entre os habitantes dos dois países foi levada ao extremo durante o longo período em que se praticou o contrabando. Este sempre marcou a zona de raia, mas, durante o período da guerra civil espanhola e das ditaduras portuguesa e espanhola, acentuou-se ainda mais e contribuiu decisivamente para o desenvolvimento económico das duas regiões.

Com a elevada onda de migração/emigração que se verificou nas aldeias fronteiriças, nas décadas de 60 e 7016, a queda da ditadura portuguesa (1974) e da ditadura espanhola (1976), a adesão à União Europeia e a abertura das fronteiras, em vez de uma maior aproximação, houve um afastamento das gentes dos dois lados da raia. Sem motivos socioeconómicos que justificassem a permanência nessas localidades, assistiu-se a uma desertificação e, consequentemente, a uma gradual perda da cultura aí existente, da qual faz parte o Falar Raiano de Marvão / Valencia de Alcántara.

Atualmente os dois municípios vão promovendo algumas atividades culturais em comum, as quais proporcionam um convívio mais estreito entre portugueses e espanhóis, mas este nem se chega a assemelhar ao que existiu outrora e, pelos caminhos do tempo, muitos conhecimentos e tradições já quase se perderam, como tem sucedido com a variedade do português falada na raia, que poucos ainda sabem e raramente praticam.

\section{Principais aspetos fonético-fonológicos do Falar Raiano de Marvão/ Valencia de Alcántara}

Em 1971, quando Lindley Cintra apresentou uma nova proposta de classificação dos dialetos portugueses, o concelho de Marvão ficou integrado na área dos dialetos portugueses centro-meridionais, no grupo de dialetos do centro-interior e sul, mais concretamente na região da Beira Baixa e Alto Alentejo ${ }^{17}$. O Falar de Marvão/ Valencia de Alcântara partilha algumas das características fonético-fonológicas identificadas pelos diversos linguistas nesta parte do Alentejo e apresenta especificidades que o distinguem de outros falares da região.

Como não faremos aqui uma descrição detalhada desta variedade dialetal, apresentaremos apenas algumas características mais vincadas e/ou que conferem originalidade ao falar.

16 Cayetano Rosado (2007: 33).

17 Cintra (1995: 141-163); Cunha (2006: 11). 


\subsection{Vocalismo tónico}

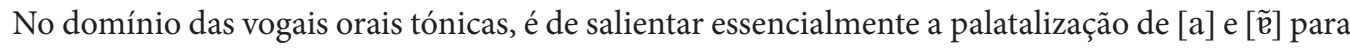
$[\varepsilon]$ e $[\tilde{e}]$ respetivamente:

- [kenevjéł] (canaviel - canavial), [bufkér] (busquer - buscar);

- [îftudếti] (estudente - estudante), [irmế] (irmẽ) - irmã).

Nas aldeias de Escusa e Porto da Espada (nesta de forma já mais esbatida), verifica-se ainda uma palatalização do $[\mathrm{u}]$ e do $[\tilde{u}]$, passando a $[y]^{18}$ e $[\tilde{y}]$ :

- [týdì] (tüde - tudo), [býrì] (bürre - burro);

- [fýdì] (funde - fundo), [ritýde] (retunda - rotunda).

\subsection{Vocalismo átono}

Nas vogais orais átonas, são de salientar as diversas mutações de timbre da vogal [e], provocadas quer por assimilação, quer por dissimilação, sendo a mais significativa o fechamento para [i]]:

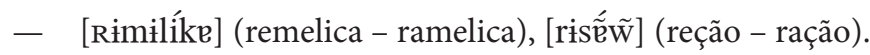

Por norma, assistimos a uma centralização e fechamento da vogal [ $\varepsilon]$ para [ $[$ ], sobretudo quando a vogal antecede uma consoante alveolar velarizada:

- [ ĩpikávøł] (impecával - impecável), [túnøł] (túnal - túnel).

A passagem de [i] a [e] e [u] representa outra marca muito vincada do Falar de Marvão. Esta resulta, em muitos casos, do fenómeno de assimilação ou da presença de uma vibrante contígua:

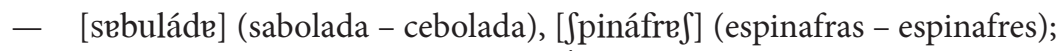

- [pupínu] (pupino - pepino), [fuvrévu] (fuvrero - fevereiro).

De registar ainda a centralização de $[\mathrm{u}]$ para $[\mathrm{i}]^{19}$, especialmente em posição postónica, a qual representa uma marca distintiva dos falantes da zona norte do concelho de Marvão e é partilhada por todas as gerações - idosos, adultos e crianças:

- [kesipíni $]$ (cachepinhe - cachopinho), [nemurádi] (namorade - namorado).

18 Cândida Baptista considera este timbre quase sistematicamente palatal como uma das características mais marcantes do falar da Escusa; Baptista (1967: 21, 22).

19 Segundo Vasconcelos, esta transformação deve-se a um fenómeno de dissimilação, embora também possa advir de outras alterações esporádicas; Vasconcelos (1987: 88). 


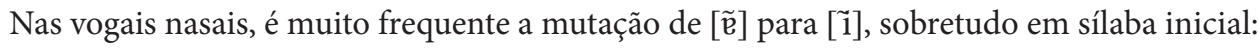

- [ibiếti] (imbiente - ambiente), [ĩ̃ínu] (incino - ancinho).

A vogal [ẽ] também apresenta diversas alterações de timbre, sendo as mais comuns a centrali-

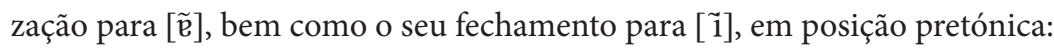

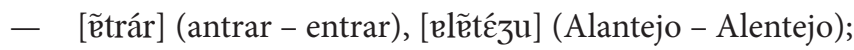

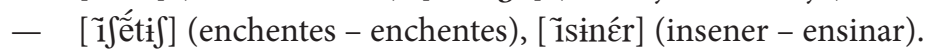

Tal como nas vogais tónicas, verifica-se uma palatalização do [ũ], passando a $[\tilde{y}]$, mas apenas caracteriza as gentes da aldeia da Escusa: [ỹtádu] (üntado - untado).

\subsection{Ditongos}

Ao fazer parte dos falares do Alentejo, o Falar de Marvão é marcado por uma forte tendência para a monotongação.

Quanto aos ditongos decrescentes orais, é de salientar a monotongação do [aj] ${ }^{20}$ (quando antecede ou segue consoante palatal) e do [uj] (somente em sílaba pretónica):

- [fáse] (faxa - faixa), [báKu] (balho - baile);

- [uvár] (uvar - uivar), [kudár] (cudar - cuidar).

No que toca aos ditongos crescentes, destaca-se a redução do [ja] em posição postónica, bem como uma transposição da semivogal para outra parte do vocábulo, motivada por uma metátese:

- [ewzếse] (ausença - ausência), [ortếse] (hortensa - hortênsia);

- [lerájpe] (laraipa - larápia), [kuméjde] (comeida - comédia).

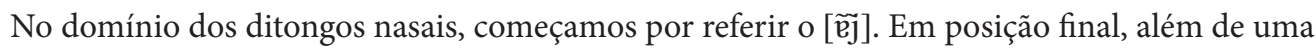
redução, verifica-se uma desnasalização ${ }^{21}$ :

- [muáze] (moaja - moagem), [órde] (orda - ordem);

Casos há em que o ditongo nasal altera para [ĩ ]:

- $\quad$ fiffésĩ $]$ (fechessim - fechassem), [ãtiốti] (antiontim - anteontem).

20 Vasconcelos (1987: 92); o linguista considera esta redução característica dos dialetos do Sul, verificando-se esta em próclise. Todavia, como podemos constatar, no Falar de Marvão este é um fenómeno mais abrangente.

21 Batista (1967: 46); além da desnasalação, Cândida Baptista registou frequentemente uma queda da semivogal final. 
Quanto ao ditongo [ $\tilde{\mathfrak{E}} \tilde{\mathrm{W}}]$, para além da monotongação (sobretudo na aldeia da Escusa), por vezes apresenta uma alteração para [ẽ̃w], o que constitui mais um traço bastante característico do falar dos marvanenses, ainda que já só dos mais idosos:

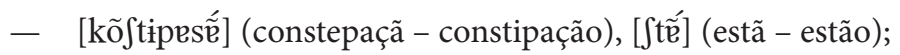

- [bałserẽ́w] (balserẽum - balseirão), [kumisẽ́w] (comessẽum - comissão), [irmẽ̃ w] (irmẽum - irmão).

Este mesmo ditongo, em posição postónica, além de reduzir, também evidencia uma desnasalização:

- [kriftóve] (Cristova - Cristóvão), [sótu] (soto - sótão).

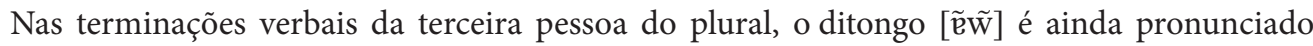
como [ [̃] ou [ẽ], o que é um traço bem vincado do Falar de Marvão:

- [fóri] (forim - foram), [ẽéávi] (andavim - andavam);

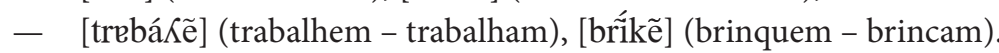

\subsection{Consonantismo}

Ao nível do consonantismo, não há uma variação tão acentuada como no vocalismo. Ainda assim, são de salientar algumas mutações, por exemplo, entre [b] e [v] ${ }^{22}$. Embora este seja um traço característico dos falares setentrionais, surgem muitos vocábulos a ilustrá-lo:

- [krevinéru] (cravenero - carabineiro), [gevóles] (gavolas - gabarolas);

- [báze] (baja - vagem), [biRúge] (berruga - verruga).

22 Vasconcelos (1987: 95); na sua perspetiva, a ausência de oposição fonológica entre [b] e [v] a favor de [b] não caracteriza a maior parte dos dialetos do Sul, à exceção de Barrancos e de Vila Real. Nestas localidades, o autor justifica essa tendência por influência do espanhol falado nas localidades vizinhas, pois nesta língua não existe atualmente o [v].

Sendo Marvão também um concelho de raia, a abundância de vocábulos em que se verifica a ausência dessa oposição fonológica a favor de [b] poder-se-á explicar desta forma, contudo, muitas são também as palavras que ilustram o fenómeno inverso, ou seja, a tendência para o uso de [v], como ilustram os exemplos acima apresentados.

Boléo (1951: 28); este autor considera a ausência de oposição fonológica muito fácil de ocorrer, especialmente entre a consoante labiodental e a bilabial fricativa: "basta uma aproximação dos lábios para se passar da primeira à segunda ou, inversamente, um ligeiro relaxamento muscular para que a bilabial se transforme em labiodental." Assim se explica que em português apareçam palavras em que o [b] surge em vez do [v] e que existam vocábulos com duas variantes de grafia e pronúncia, como sucede com "taberna e taverna, cobarde e covarde".

Ossenkop (2006: 670); de acordo com a autora, ao contrário do que sucedeu em Herrera, em que se verificou um "betacismo", ou seja, um predomínio do $b$ em relação ao $v$, nas povoações fronteiriças de Valencia de Alcántara, mantém-se a oposição fonológica entre /b/ e / v/. Este panorama linguístico justifica a pouca influência desse traço da língua espanhola nas localidades de raia, como é o caso de Porto da Espada, Fronteira, Galegos, Pitaranha, Santo António das Areias e Beirã. 
De destacar também a palatalização de $[1]^{23}$ e [n], quando seguidas da semivogal palatal [j], passando a $[K]$ e $[n]$ respetivamente:

- $\quad$ [emî $氏$ e] (Emilha - Emília), [femîKe] (familha - família);

- [ermóni] (harmonhe - harmónio), [m̌̃́ne] (manha - mania).

\section{Principais aspetos morfossintáticos}

Algumas das características morfossintáticas deste falar distinguem-no claramente da norma e conferem-lhe originalidade no panorama dialetal da região.

$\mathrm{Na}$ classe do nome, é de referir a formação do plural nos vocábulos terminados em lateral alveolar. Contrariamente à língua padrão, apresentam uma terminação regular, com manutenção do - 1 - intervocálico, a qual poderá dever-se à proximidade com Espanha e à formação dos plurais no castelhano:

— [pepélif] (papeles - papéis), [kerckólif] (caracoles - caracóis).

Nas classes dos determinantes e dos pronomes também se verificam algumas alterações, entre as quais destacamos o uso dos demonstrativos "aquesse(s)", "aquessa(s)", em vez de "esse(s)", "es$\mathrm{sa}(\mathrm{s})$ ". Estamos, assim, perante formas medievais típicas do galego-português que se conservaram neste falar até à atualidade. De notar que este uso se verifica somente nas aldeias mais isoladas e por parte dos falantes mais idosos.

- "Aquesse rapaz nã mé 'stranho."

- "Aquessa rapariga é da Portaja."

O mesmo se passa com as formas "aqueste(s)", "aquesta(s)", em vez de "este(s)", "esta(s)":

— "Naquesta terra é qu'ê narci."

- "Naqueste bairro tudo se conhece."

No vasto paradigma dos verbos, verificam-se diversas alterações relativamente à norma, entre as quais destacamos a flexão do gerúndio em todas as pessoas:

- "Im andando doente, nã tanho paciença niuma."

- "Em acabandes isso, podes ir."

De salientar ainda o facto de alguns idosos conjugarem os verbos na segunda pessoa do plural usando formas verbais arcaicas:

23 Vasconcelos (1987: 94); o autor considera este fenómeno a continuação moderna do fenómeno de palatalização de $[1]$ em $[\lambda]$ por influência de uma semivogal palatal, dando origem a palavras do tipo "filha", do lat. FILIA. 
- "Vocês ganhêdes poco, mas ainda fazêdes menos."

- "Hoje nã fôrindes lá de prepóseto."

Por ser usada atualmente por poucos falantes na zona da raia e estar prestes a desaparecer, registamos aqui a conjugação do verbo "andar" no pretérito perfeito recorrendo ao - v- intervocálico:

- andive, and'vestes, andeve, and'vemos, and'veram/em (andei, andaste, andou, andámos, andaram).

No âmbito da morfologia verbal, destacamos ainda o uso frequente de expressões idiomáticas em substituição de verbos:

- subir o cascalho (zangar-se);

- dar a mão de amigo (cumprimentar).

\section{Léxico}

O plano lexical é aquele em que Falar Raiano de Marvão revela maior originalidade e mais se demarca de outros falares alentejanos.

No que toca aos processos de criação, renovação e enriquecimento do léxico, surgiram-nos muitas diferenças relativamente à norma, pelo que apresentamos aqui somente uma pequena amostra.

Relativamente à derivação, há diversos casos de prefixação, sufixação e parassíntese, como ilustram os exemplos:

- espalmilhado (sem palmilha), esvoltenher (remexer em busca de algo);

- ovelhada (conjunto de ovelhas), sameação (sementeira);

- arremangado (arregaçado), empatalosado (com características de patalô).

Quanto ao processo de composição, muitos são os exemplos que recolhemos de composição morfossintática:

- catracego (cego, zarolho), arco-da-velha (arco-íris), cão-de-gaveta (dívida), nol-da-sopa (maçã-de-adão).

No que diz respeito ao empréstimo de castelhanismos, este varia nos dois lados da fronteira. Nas aldeias portuguesas, a população, por norma, tem bem presente o que é o português e o espanhol, por isso, não mistura as duas línguas. Já em solo valenciano há uma maior interferência da norma, surgindo nas conversas em raiano muitas mais formas do castelhano. Assim, optámos por apresentar aqui somente exemplos de vocábulos que registámos nos dois lados da fronteira. Estes castelhanismos são essencialmente nomes, havendo também alguns adjetivos, verbos e expressões idiomáticas: 
- pelota (bola), cino (cinema), ince (entorse), lavadurina (fermento);

- encelado (ciumento), garanhão (homem mulherengo), guapa (bonita);

- agachar-se (defecar), sajunar (tomar o pequeno-almoço), andar à morena (espalhar a confusão).

Mais frequentes neste falar raiano são os arabismos. Para além da influência da língua árabe no Português em geral, não podemos deixar de relembrar o quanto a presença deste povo foi marcante no desenvolvimento de Marvão, a começar pelo fundador da fortaleza - o muladi Ibn Maruán. A longa presença dos árabes deixou marcas na cultura dos marvanenses em geral, na toponímia e em diversos aspetos do seu falar. Assim, surgem-nos arabismos ${ }^{24}$ pertencentes a diferentes campos léxico-semânticos ${ }^{25}$ :

- Toponímia - Marvão, Alvarrões, Alcántara, Cabeço de Mouro, Safra Alta;

- Terra - arrife, barroca, chaboco, safra, talefo;

- Agricultura - alcacero, aljaroz, alqueve, lambique, talego;

- Animais - arvela, alacrau, caçapo, farropo, farum;

- Plantas - abroita, alvarrã, beldoega, saragaço, xara;

- Objetos - acincho, alpargata, amentolia, cocharra, zabumba;

- Profissões - almocreve, balfurnhero, cefador, gatero, zagal;

- Habitação urbana e rural - almenzém, arrebena, choça, lagareta, pial;

- Alimentação - amassadura, atabefe, barranhão, mexorfada, talhada;

- Corpo humano e aspeto físico - alganaça, bicanca ${ }^{26}$, enjorcado ${ }^{27}$, xarifa, zangalhão ${ }^{28}$;

- Comportamentos e atitudes - alarido, aldruga ${ }^{29}$, almanaque, almariado ${ }^{30}$, zagalona $^{31}$;

- Diversos - anexim, denguice, escalmurra ${ }^{32}$, lagarice, safrenho.

24 Para comprovar a origem árabe dos vocábulos apresentados, baseámo-nos em diversos artigos (indicados na bibliografia final) e consultámos essencialmente o Dicionário Houaiss, na sua rubrica de etimologia, bem como Sousa 2004, Machado 1991, Vargens 1999 e Alves 2013. Ao fazer essa análise, deparámo-nos com opiniões diversas. Assim, quando tal se verificou, optámos por seguir a obra mais recente e mais desenvolvida, nomeadamente Alves 2013. De referir que este autor justificou a maior abrangência da sua obra (18073 entradas) pela inclusão no seu dicionário de palavras "cujo étimo árabe nos chegou por intermediação de outras línguas, e ainda aquelas cujo étimo foi introduzido através do árabe embora a sua origem remonte a étimos como o persa, o turco, o hindi, o grego ou o latim.” Acrescentou ainda que "contempla quer as palavras ditas primitivas [...] quer as derivadas, ou seja, as que nasceram a partir daquelas, por força do processo formativo intrarromânico antigo, ou já no português moderno." Alves (2013: 35).

25 Atendendo ao considerável número de exemplos apresentados, para consulta dos significados, recomenda-se a leitura da obra Simão 2016 ou Simão (2015: 132-243).

26 Alteração de "picanca".

27 Alteração de "ajorcado".

28 Derivação de "zangalho" - indivíduo alto e enredado; desajeitado.

29 Deturpação de "aldruba" - aldrabão, mentiroso.

30 Por analogia com "almareado" - estonteado, nauseado.

31 Por analogia com "zagal” e "zagala”.

32 Derivação de "calma" - calor do sol. 
A análise contrastiva que estabelecemos com os dicionários de referência que escolhemos ${ }^{33}$ permitiu-nos aferir que vocábulos se encontram indicados como regionalismos e quais os que não estão dicionarizados nessas três fontes.

Assim, da recolha total, apenas $9 \%$ do léxico surge assinalado como regionalismo. Esses vocábulos $^{34}$ pertencem a vários campos léxico-semânticos:

- Terra - arrife, canada, machoca, patamero, presa;

- Agricultura - arrelvar, atalhar, baleio, picota, talera;

- Animais - aprisco, avental, fura-pastos, malata, suã;

- Plantas - carrapiço, carrasquera, palanco, saragacinha, tocera;

- Objetos - altesa, caço, camila, esquila, jangoto;

- Alimentação - carapulo, landoque, murraça, pendura, ponilha;

- Corpo humano e aspeto físico - alacado, entorado, mirentes, sunisga, zomba;

- Comportamentos e atitudes - acarear, charepa, avezar, enganido, trambelho;

- Diversos - assestida, bonda, candonga, morrinha, treguera.

No que diz respeito ao léxico por nós elencado, cerca de 2900 entradas ${ }^{35}$, 30\% não se encontra registado nos dicionários de referência, o que é revelador da sua originalidade. Este vocabulário característico do Falar Raiano de Marvão / Valencia de Alcántara pertence a diversas classes de palavras, havendo um predomínio de verbos, adjetivos e expressões idiomáticas. Distribui-se por vários campos léxico-semânticos, embora o dos comportamentos e atitudes seja o mais abundante. Em seguida apresentaremos alguns exemplos; numa primeira fase, vocábulos de diversas classes e, numa segunda fase, somente expressões idiomáticas ${ }^{36}$.

- Terra e fenómenos atmosféricos - aguarrechedo, bolandero, calhega, chabarco, verguentas;

- Agricultura e alfaias agrícolas - afaiancar, desensamarração, guarda-ladrão, lavrega, tentemoço;

- Animais - áspia, avoinha, gachela, lutrir, machagolo;

- Plantas - amor-de-mãe, fotricas, gazulo, inchona, mel-de-bruxa;

- Objetos - borloto, carrucha, espercha, panela-dos-lavradores, pano-pão;

- Habitação e adereços - apindico, cajereum, chafurdão, chinquera, mesa-de-pastor;

- Alimentação - bolo-da-festa, cachafrito, cloque, manta-de-gatero, testo-de-panela;

- Corpo humano e aspeto físico - aimano, cabras, daipano, entripal, ventas-de-panico;

- Doenças - aplomesia, belancoso, bramura, ceganhuto, folinhas;

- Comportamentos e atitudes - afarracatar-se, arrenguelha, esbalagar, froar, gajiar.

33 Como referência, escolhemos o Dicionário do Português Atual Houaiss (Villar 2011), o Grande Dicionário da Língua Portuguesa, de Cândido de Figueiredo (Figueiredo 1996), e o Dicionário da Língua Portuguesa Contemporânea, da Academia das Ciências (Casteleiro 2001).

34 Devido ao considerável número de exemplos apresentados, para consulta dos significados, recomenda-se a análise da obra Simão 2016 ou Simão (2015: 132-243).

35 Presentes em Simão 2015 e Simão 2016.

36 Para consulta dos respetivos significados, recomendamos a leitura de Simão (2015: 132-243) ou Simão 2016. 


\section{Expressões idiomáticas}

- Animais - bradar à rosa, detar a barriga, estercar a bardo;

- Técnicas agrícolas - cavar ó camalhão, dar terras à matação, vender à carga cerrada;

- Alimentação - comer o bolo, comer do barranhão, entrar o bispo na panela;

- Trabalho - trabalhar de saco aviedo, meter-se a requerimentos, trazer uma gaita;

- Bebedeira - ir de rebimbalho, ir de regangamalho, nã ir munto católeco;

- Ato de defecar - arriar o melão, ir à murelha, pregar uma falsa;

- Comportamentos - passar-se à cortina, vender lampanas, matar a formiga.

\section{Alterações no plano semântico}

No domínio da semântica verificam-se também diversas alterações.

Ao fazermos o confronto da nossa recolha com os três dicionários de referência que elegemos, concluímos que, por vezes, os vocábulos encontram-se registados, mas na região de Marvão/Valencia de Alcántara têm outra aceção. Assim, surgiram-nos casos de:

- Ampliação - almocreve (criado de servir), chancalho (algo que já não presta), talegada (pequena porção existente no fundo de um saco);

- Restrição - balça (silva), descante (baile do casamento), suciar (beber em conjunto com);

- Mudança - abrunhar (ter medo), galenhero (homem que está sempre em casa e não convive com os outros na taberna), serventia (vagina dos animais).

\section{Variação diacrónica, diastrática e diafásica}

Analisada a mutação da língua em função do espaço em que é usada, há que abordar brevemente a sua variação motivada pela passagem do tempo, pelas características dos falantes e as circunstâncias em que ganha vida. No que diz respeito a estes três tipos de variação, registámos bastantes diferenças em solo português e espanhol, por isso, apresentá-las-emos separadamente.

\subsection{Variação em território marvanense}

No que toca à variação diacrónica, apenas podemos apresentar a evolução do falar na aldeia da Escusa, pois, antes da nossa investigação, só existia uma tese de licenciatura dedicada ao estudo do falar dessa aldeia, datada de 1967, da autoria de Cândida Baptista ${ }^{37}$. Assim, em cerca de quarenta anos, notámos algumas diferenças, sobretudo nos domínios fonético-fonológico e lexical.

Quanto ao primeiro, destacamos atualmente um menor recurso à monotongação. Por exemplo,

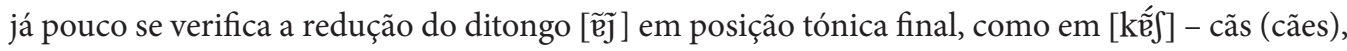




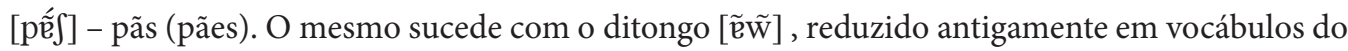

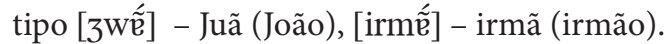

Relativamente ao léxico, constatámos aquilo para que nos alerta Margarita Correia ${ }^{38}$ : "De entre as componentes do conhecimento linguístico, o léxico é [...] aquela em que a variação que ocorre ao longo dos tempos (diacrónica) é mais visível. Constituindo o ponto de cruzamento entre a língua e a realidade extralinguística, ele reflecte a evolução desta, o surgimento de novas realidades, de novos conceitos e até de novas perspectivas sobre a realidade." Assim, na década de 60 do século passado, houve um registo muito significativo em alguns campos léxico-semânticos, designadamente, agricultura, extração da cal, moinho, linho, vocabulário a que já não tivemos acesso tão abundantemente aquando da aplicação do nosso inquérito. Alguns dos informantes dessa altura já tinham falecido e aqueles mais idosos que inquirimos há muito que haviam deixado essas atividades, esses objetos, banindo consequentemente da sua linguagem uma parte significativa desse léxico. Quanto aos mais novos, muitos desses saberes já não passaram para as gerações seguintes; nuns casos, porque os jovens enveredaram por outras atividades, noutros, porque as novas tecnologias e os novos métodos de trabalho vieram substituir muitos dos antigos usos.

No que diz respeito à variação diastrática do falar, debruçamo-nos essencialmente sobre a influência da idade e do grau académico nos falantes, embora estes fatores não possam ser analisados isoladamente da sua profissão/ ocupação regular, pois estão intimamente associados. O facto de termos aplicado inquéritos a informantes de todas as camadas etárias e com graus de escolaridade muito distintos permitiu-nos apurar como a idade e a escolaridade interferem na maneira de falar dos marvanenses. Quanto mais velhos e menos escolarizados são os falantes, mais preservam as características desta variedade linguística. À medida que descemos nas camadas etárias e o grau de escolaridade aumenta, mais se vão perdendo as marcas distintivas do falar.

Assim, verificaram-se diferenças ao nível da fonética e fonologia, morfologia e sintaxe e no domínio do léxico. Por exemplo, nos mais jovens, no vocalismo tónico, já não existe a palataliza-

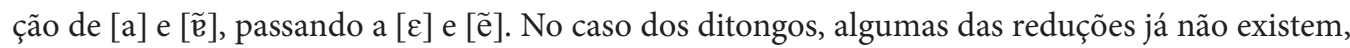

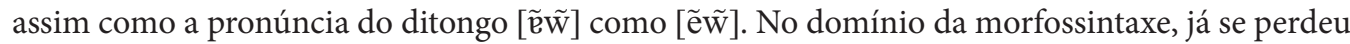
o -l- intervocálico no plural das palavras terminadas em lateral alveolar $<\mathrm{l}>$ no singular, bem como o uso dos determinantes e pronomes demonstrativos "aquesse/aquessa" e "aqueste/aquesta", ou as formas arcaicas na conjugação do verbo na segunda pessoa do plural ("vocês ganhêdes"), entre outras. No que respeita ao léxico, os mais novos desconhecem muitos termos da fauna e da flora, assim como muito vocabulário associado aos ofícios de antigamente e à agricultura, pois a realidade em que se inserem proporciona-lhes outras aprendizagens. Sendo assim, uma parte significativa dos vocábulos/ expressões respeitantes a realidades do antigamente é conservada somente pelos mais idosos e por alguns adultos. Algumas exceções verificam-se em aldeias mais isoladas e no seio de um agregado familiar com pouca escolaridade, mas o convívio escolar dos jovens e a sua saída do concelho para prosseguir estudos facilmente alterarão essa genuinidade.

Quanto à variação diafásica, destacamos aqui a saída dos jovens marvanenses para dar continuidade aos estudos em Portalegre. Enquanto estudam no concelho de origem, apesar da escolaridade que vai aumentando, mantêm na oralidade muitos dos traços do falar. Quando ingressam no ensino secundário, os alunos confrontam-se com colegas de vários pontos do distrito e aper- 
cebem-se de que certas marcas da sua oralidade não são partilhadas pelos demais, logo, tendem a omiti-las e a usar em exclusivo a língua padrão, situação que nada favorece a continuidade da variedade regional.

\subsection{Variação em território de Valencia de Alcántara}

Ao longo do século XX foram desenvolvidos alguns trabalhos de investigação sobre a zona da raia, os quais nos permitem ter uma base de comparação com a situação atual.

Como antes referido, na área política do concelho de Marvão, a idade tem uma importância grande no maior ou menor domínio das características do falar regional; nos lugares e aldeias da raia espanhola por onde se estende o raiano, esse fator é decisivo. Segundo Juan Carrasco ${ }^{39}$, em 1900, mais de 90\% dos habitantes desses locais falavam exclusivamente o dialeto fronteiriço; em 2000, 100\% conheciam e falavam o castelhano. Baseando-se nos censos de 2001, o linguista refere que nesses aglomerados populacionais de Valencia de Alcántara os dialetos fronteiriços eram falados ainda por adultos acima dos 30 anos, sendo todos bilingues. Acrescenta que, tendo por base os dados referentes a todas as aldeias da raia valenciana, a população totalizava 850 habitantes, havendo $630(74,11 \%)$ que falavam o dialeto ${ }^{40}$, ou seja, no início do século XXI, somente 220 (25,8\%) não o dominavam. Contudo, conhecendo nós bem a realidade atual desses locais, os dados dos censos induzem-nos em erro, pois o número de pessoas que consta dessa estatística é completamente diferente do número de habitantes que diariamente aí vive. Na verdade, muitos naturais de Valencia de Alcántara e seus arredores mantêm-se lá recenseados, mas há bastante tempo que migraram. Estes sabem falar o raiano e alguns têm menos de 60 anos, mas, no dia-adia das localidades de fronteira, só muito acima dessa idade se ouve essa variedade linguística e já nem todos os residentes a dominam. Aliás, há aldeias em que somente quatro ou cinco pessoas a utilizam. Apenas no verão, no período de férias, essa situação se inverte, quando os filhos da terra regressam.

Em 2013/2014, quando aplicámos os inquéritos linguísticos nas localidades espanholas da raia, deparámo-nos com um falar regional em risco de sobrevivência. São raros os adultos abaixo dos 50 anos que ainda dominam o raiano. Acima desse nível etário encontramos alguns, variando a percentagem de aldeia para aldeia. Se nuns locais a maioria continua a dominar esta variante linguística (como por exemplo na Fontañera), noutros já muito poucos a conhecem (como sucede em Las Huertas). Independentemente do seu grau de instrução, é de notar que atualmente todos os falantes que ainda dominam a variedade raiana são bilingues, verificando-se uma situação de adstrato entre o português da raia e o castelhano.

Entre 1970 e 1980, a maioria dos habitantes (monolingue ou bilingue) não transmitiu esse conhecimento aos seus descendentes. O acesso ao ensino básico passou a ser obrigatório, nas localidades da raia foram construídas escolas primárias e as crianças que em casa falavam português, melhor dizendo, raiano, tinham muitas dificuldades em aprender castelhano. Como todas as matérias na escola eram ministradas na língua oficial de Espanha, isso constituía uma grande

\footnotetext{
39 Carrasco $(2007: 62,63)$.

40 Carrasco (2007: 64).
} 
desvantagem e era um promotor de insucesso escolar. Assim, os pais optaram por poupar os mais novos a tais dificuldades. Também a forte onda de emigração/ migração que se verificou na Extremadura e nas aldeias da raia, em concreto, foi determinante para que os progenitores não ensinassem a variedade regional aos seus descendentes.

Quando questionados os vários informantes sobre essa situação, todos eles já bilingues, muitos demonstraram arrependimento por não terem ensinado aos seus filhos, a par do castelhano, o raiano, reconhecendo ser agora difícil inverter essa realidade. Em algumas famílias, uma parte dos descendentes sabe essa variante do português, e usa-a regularmente com os seus progenitores, e a outra parte somente fala castelhano. Assim, um mero encontro familiar é propício à ocorrência de fenómenos verbais bilingues. Presenciámos também conversas telefónicas entre pais e filhos que falam raiano. O diálogo desenrolou-se essencialmente nessa variedade linguística, mas as despedidas foram em castelhano. Essas situações de alternância de códigos linguísticos, se nada for feito em contrário, tenderão a perder-se.

Na verdade, ausente das escolas, da administração pública, dos media, no fundo, de tudo o que circunda os falantes, a variante portuguesa da raia ficou social e linguisticamente desprestigiada, o que provocou um crescente desinteresse por ela.

Apesar de a cultura lusófona ainda estar muito presente em algumas aldeias ${ }^{41}$, o falar da raia vai paulatinamente desaparecendo ${ }^{42}$ e só os mais audazes e os que continuam a ter um verdadeiro orgulho na sua primeira língua (o português raiano), agora já muito castelhanizada, é que continuam a falá-la, mas são cada vez menos.

Nesses casos, se nos domínios fonético-fonológico e morfossintático ainda não há muitas interferências do castelhano, no âmbito do léxico, bastantes palavras caíram no esquecimento, sendo substituídas pelas correspondentes da língua espanhola. Esse processo afetou não só o vocabulário relativo a novas realidades da atualidade, como também muito referente a objetos e profissões de antigamente. Ao falarem português, os habitantes das localidades raianas de Espanha facilmente introduzem léxico do espanhol, contudo, o contrário já não se verifica.

À medida que o tempo flui, os idosos das aldeias de raia vão partindo e a regeneração não é garantida, assumindo o castelhano um protagonismo cada vez maior. Como já foi referido, a decisão dos pais de não continuarem a transmitir a sua língua materna aos seus descendentes marcou o início da decadência desta variedade geográfica do português, pois seriam as crianças, mesmo que bilingues, que garantiriam a sua sobrevivência. Nas localidades raianas, só a implementação de medidas que visem atrair a curiosidade dos jovens e o seu gosto pelo raiano poderá inverter um ciclo que caminha a passos largos para o fim.

Atualmente, em Valencia de Alcántara é ensinado o português como língua estrangeira nas escolas e até existem alguns cursos de formação para adultos; no entanto, no que ao raiano diz respeito, não há qualquer ensino nem promoção. Os idosos constituem, assim, a única esperança desta variedade linguística que, se nada for feito em solo politicamente espanhol, terá um "prazo de duração" de sensivelmente 20/30 anos.

41 Por exemplo, em La Fontañera, em algumas festas populares, tivemos oportunidade de assistir ao início de bailes improvisados pelos convivas, os quais foram abertos com músicas portuguesas e não espanholas.

42 Em 2006, já Juan Carrasco se reportava ao desaparecimento das falas fronteiriças nos próximos anos e citava o testemunho de outras investigadoras de falares da raia a esse propósito, nomeadamente, Maria de Fátima Matias e Maria da Conceição Vilhena; Carrasco (2006: 624, 625). 


\section{O que fazer para reverter a tendência de desaparecimento?}

Enquanto património imaterial ou intangível, um falar constitui um património vivo, que vai sendo transmitido de geração em geração e recriado pelos falantes que lhe dão vida, logo, faz parte da sua identidade. Contudo, essa imaterialidade torna-o mais frágil. De acordo com os critérios de vitalidade da UNESCO, no concelho de Marvão, esse falar encontra-se "vulnerável”; tem passado de geração em geração, mas as crianças só partilham algumas das suas características. Já em solo espanhol, está "seriamente em perigo". Aí é usado apenas por alguns avós, muitos pais não o sabem e ninguém o transmite aos netos.

Perante a evolução dessa variedade linguística, é necessário continuar a tomar medidas céleres para inverter a tendência de gradual desaparecimento nessa região, à semelhança do que vai sucedendo em muitos outros sítios. Para além de trabalhos de investigação e sistematização das suas características, muito mais há a fazer para manter vivo esse traço identitário dos marvanenses e dos habitantes da raia espanhola. Antes de mais, é preciso continuar a demonstrar-lhes o quanto é imprescindível preservar o seu modo de falar e a necessidade de o transmitirem às gerações vindouras ${ }^{43}$. Nesse sentido, além de iniciativas individuais como as que temos desenvolvido, quer em solo português, quer em solo espanhol, será importante a ação dos organismos locais; afinal, esse falar raiano representa uma importante componente do património cultural imaterial do Nordeste do Alentejo e de uma parte da raia da Extremadura.

A salvaguarda desse tipo de património, para além dos especialistas, deverá envolver as comunidades e os grupos que o mantêm vivo. Em Marvão, só recentemente tem vindo a surgir essa consciencialização na comunidade, mas ainda há um longo caminho a trilhar.

Segundo a Declaração de Yamato sobre a Abordagem Integrada para a Salvaguarda do Património Cultural, Material e Imaterial, em 2004, tendo em consideração a interdependência e as diferenças entre património natural e património cultural, material e imaterial, bem como as diferenças na abordagem da sua salvaguarda, recomenda-se que sejam levadas a cabo abordagens integradas, pois contribuem para uma maior consciência da importância desse legado e trarão mais benefícios para a sua conservação e divulgação.

Como muitos documentos da UNESCO destacam, no âmbito do imaterial, as línguas assumem um papel decisivo, pois funcionam como veículo de transmissão de todos os saberes ancestrais, entre eles as tradições e o saber fazer. $O$ falar raiano de Marvão é um exemplo bem evidente dessa realidade; muito do léxico que o integra refere-se a costumes e tradições da região ou foi recolhido ao mesmo tempo que se apuravam exemplos da sua literatura oral tradicional, estando alguns desses conhecimentos também em perigo de ser esquecidos.

Para além das instituições/ organismos existentes, seria importante a fundação de uma associação de investigação centrada na cultura e na língua, à semelhança do que já existe noutras zonas de fronteira, como por exemplo, na Serra da Gata e Val de Xalma. Aliás, essa é uma região que se revela como modelo de preservação das suas variedades linguísticas, quer por parte dos seus habitantes, quer por parte das entidades competentes. A saber, o Governo Autónomo da Extremadura reconheceu essa necessidade de proteção no Decreto 45/2001, de 20 de Março, da Consejería de

43 A este propósito, não podemos deixar de lembrar a atitude dos falantes do Val de Xalma, que sempre tiveram orgulho no seu falar, continuam a usá-lo em todas as circunstâncias do seu dia-a-dia e preocupam-se em transmiti-lo aos seus descendentes, contribuindo, assim, de forma decisiva, para a sua vitalidade atual. 
Cultura: "por el que se declara Bien de Interés Cultural la «A Fala»". Ficou a faltar a definição de medidas de preservação e divulgação, como estão a ser postas em prática, por exemplo, na região de Minde, relativamente ao minderico.

Na zona da raia de Marvão/ Valencia de Alcántara, não existe, até ao momento, nenhuma instituição dessa natureza, representando a sua constituição e dinamização, para nós e para outros amigos da cultura raiana, um desafio futuro. Atendendo à riqueza patrimonial existente na região, defendemos mesmo a criação de um Centro UNESCO, através do qual será mais fácil consciencializar a população em geral para a necessidade da salvaguarda, registo e dinamização do seu património cultural.

Em território espanhol também se têm realizado algumas iniciativas com vista à recuperação dos saberes ancestrais e até à dinamização de alguns deles. Existem diversas publicações, desde artigos, a livros, a revistas, a blogues, sendo a maioria centrada essencialmente no registo. Ainda assim, o Ayuntamiento de Valencia de Alcántara e algumas associações locais têm promovido eventos em que proporcionam o uso de muitos desses saberes. No que diz respeito à Universidade de Cáceres, foram realizados diversos trabalhos de investigação, mas continuam a faltar iniciativas de promoção do falar da raia no terreno em que esse se enquadra. Finalmente, é ainda de destacar o Grupo de Coros y Danzas Juéllega Extremeña, fundado em 1980 e que, desde então, tem recolhido e divulgado o folclore e a cultura da Extremadura, dedicando uma atenção especial à Campiña, na qual várias aldeias são de fronteira e existe uma forte influência da cultura portuguesa. Tal como sucede no lado português, na raia espanhola, é ao nível da gastronomia e do folclore que se verifica uma maior dinamização desses saberes. Do ponto de vista linguístico, é importante continuar a trilhar o caminho já iniciado e intensificar atividades de promoção e uso do raiano.

À semelhança de outros locais, é necessário continuar a unir esforços nos dois lados da fronteira, no sentido de promover momentos de divulgação do falar local. Assim, é fundamental que se promovam eventos em que os falantes, especialmente os mais idosos, possam evidenciar os seus saberes nesse domínio, interagir com as gerações mais novas, e ensinar-lhes o que a vida lhes proporcionou informalmente.

A escola desempenha um papel decisivo na imposição da norma em detrimento das variedades dialetais, contudo, no contacto com alunos do terceiro ciclo, verificámos que muitos se interessavam pelo património imaterial do seu concelho. Os vários trabalhos de pesquisa que lhes propusemos foram realizados com imenso empenho, mesmo por aqueles que revelavam desinteresse pelo ensino. Para além da promoção do património local, numa fase em que muitos discentes revelam desânimo em relação ao contexto escolar, esta seria seguramente uma boa forma de os motivar e de lhes fazer sentir que a escola, a par de outros conteúdos, de âmbito nacional e internacional, também lhes ensina aspetos da cultura local, que, precisamente por estarem mais próximos da sua realidade, poderão constituir a motivação que lhes faltava para irem mais além nas suas aprendizagens.

Ainda no contexto escolar, existem diversos clubes, bem como atividades de enriquecimento curricular (vulgarmente conhecidas por A.E.C.), que poderiam ser aproveitados para a promoção do património cultural imaterial e em especial dos falares. Se é um facto que, motivados e despertos para o efeito, os alunos aderem com gosto, esta seria uma excelente forma de continuar a divulgar e promover o uso de algo que poderá perder-se, se nada acontecer em contrário. Algumas 
atividades desse género têm sido promovidas em Minde e na Serra da Gata e sabemos que têm resultado muito bem.

Uma vez que o trabalho em parceria proporciona sempre a obtenção de melhores resultados, porque não candidatar o Agrupamento de Escolas de Marvão à Rede de Escolas Associadas à UNESCO? Tal candidatura só traria vantagens para o processo de ensino-aprendizagem, bem como seria seguramente mais uma forma de despertar a comunidade para a importância de valorizar a sua identidade em todas as vertentes, tornando a escola num ator interatuante com a cultura, a sociedade, a economia e o ambiente.

\section{Conclusão}

Marvão e Valencia de Alcántara são dois municípios que, ao longo da história, tiveram um passado muito em comum. Desde sempre houve um contacto muito estreito entre as suas gentes, por motivos muito diversificados, e cedo se começou a gerar uma cultura de raia, da qual o falar local faz parte.

Como se pode constatar, essa variedade linguística raiana, ainda que partilhe muitas características dos falares do Alentejo, demarca-se deles por diversas particularidades fonético-fonológicas, morfossintáticas, léxico-semânticas, o que lhe confere originalidade no panorama dialetal alentejano e português.

O século XX ficou marcado pelo apogeu da cultura raiana e também o seu declínio. Até à década de 50, o convívio entre marvanenses e valencianos era diário, havia um relacionamento muito próximo e nesse espaço era usada essencialmente a variedade regional portuguesa, por muitos designada como raiano. Com a forte onda de migração/emigração que marcou as localidades dos dois lados da fronteira e uma quebra na natalidade, o pico demográfico de 1940/1950 deu lugar a uma descida que nunca mais conheceu uma reversão e que veio a marcar decisivamente a dinâmica desse espaço e a sua cultura. A redução drástica dos falantes, a obrigatoriedade de frequentarem o ensino oficial, a influência contínua dos media, entre outros fatores, contribuíram para que a variedade linguística local, que era entendida como algo natural e parte da cultura de cada um, passasse a ser encarada de outra forma. Especialmente nas aldeias espanholas, o raiano começou a ser visto como algo que dificultava a aprendizagem da língua padrão, algo que diferenciava pela negativa, logo, deixou de haver interesse em aprendê-lo. Em solo português, o panorama tem sido um pouco diferente, não tem havido uma perda tão significativa, mas a maior parte das características desta variedade dialetal já não chega às gerações mais jovens.

Assim, há que reunir rapidamente esforços dos dois lados da fronteira para inverter a situação e não deixar que esta importante componente do património imaterial da região se perca, desaparecendo também uma parte da identidade das suas gentes. 


\section{Referências bibliográficas}

Alonso de la Torre, J. (2006). La Frontera que nunca existió. Mérida: Editora Regional Extremeña.

Alves, A. (2013). Dicionário de Arabismos da Língua Portuguesa. Lisboa: Imprensa Nacional Casa da Moeda.

Amante, M. F. (2007). Fronteira e Identidade - Construção e Representação Identitárias na Raia Luso-Espanhola. Lisboa: Universidade Técnica de Lisboa, Instituto Superior de Ciências Sociais e Políticas.

Azevedo, M. L. (2005). Toponímia Moçárabe no Antigo Condado Conimbricense. Dissertação de doutoramento apresentada à Faculdade de Letras da Universidade de Coimbra.

Baptista, C. (1967). O Falar da Escusa. Dissertação de licenciatura apresentada à Universidade de Lisboa.

Boléo, M. P. (1942). O Estudo dos Dialectos e Falares Portugueses. Coimbra: Universidade de Coimbra.

- (1951). Dialectologia e História da Língua. Isoglossas Portuguesas. Boletim de Filologia, XII, 1-44.

. (1974). Estudos de Linguística Portuguesa e Românica. Vol. I Dialectologia e História da Língua.

Coimbra: Acta Universitatis Conimbrigensis.

Bueno Rocha, J. (2000). Notas para la Historia de Valencia de Alcántara. Cáceres: Diputación Provincial de Cáceres (Institución Cultural el Brocense).

Cabral, C. B. (2011). Património Cultural Imaterial - Convenção da Unesco e seus contextos. Lisboa: Edições 70.

Carrasco González, J. (1997). Hablas y Dialectos Portugueses o Galaico-Portugueses en Extremadura (Parte II y última: Otras Hablas Fronterizas; Conclusiones. Anuario de Estudios Filológicos, XX, 61-79.

- (2006). Evolución de las hablas fronterizas luso-extremeñas desde mediados del siglo XX: Uso y pervivencia del dialecto. Revista de Estudios Extremeños, LXII, 2, 623-635.

- (2007). Falantes de dialectos fronteiriços da Extremadura espanhola no último século. Limite:

Revista de Estudios Portugueses y de la Lusofonía, 1, 51-69.

Casteleiro, J. M. (coord.) (2001). Dicionário da Língua Portuguesa Contemporânea. 2 vols. Lisboa: Editorial Verbo/ Academia das Ciências de Lisboa.

Cayetano Rosado, M. (2007). Emigración extremeña en el siglo XX - Del subdesarollo heredado a los retos del futuro transfronterizo. Extremadura: Consejería de Bienestar Social. Dirección General de Migraciones. Junta de Extremadura.

Cintra, L. L. (1971). Nova Proposta de Classificação dos Dialectos Galego-Portugueses. Boletim de Filologia, XXII, 81-116.

. (1983). Estudos de Dialectologia Portuguesa. (2. ${ }^{\text {a }}$ d.) Lisboa: Sá da Costa Editora.

Coelho, P. L. (2001). Terras de Odiana - Subsídios para a sua história documentada. Medobriga-Aramenha -Marvão Ibn Maruan - Revista Cultural do Concelho de Marvão, 11 (ed. especial). Lisboa: Câmara Municipal de Marvão, Edições Colibri. (fac-simile da edição de 1924)

Correia, M. (1999). A denominação das qualidades - contributos para a compreensão da estrutura do léxico português. Lisboa. Dissertação de Doutoramento em Linguística Portuguesa apresentada à Faculdade de Letras da Universidade de Lisboa.

Costas González, X. H. (2013). O valego. As falas de orixe galega no Val do Ellas (Cáceres - Estremadura). Vigo: Edicións Xerais de Galicia.

Cunha, C.; \& Cintra, L. (1985). Breve Gramática do Português Contemporâneo (18 ed.). Lisboa: Edições João Sá da Costa (2006).

Figueiredo, C. (1996). Grande Dicionário da Língua Portuguesa. 25. a edição. 2 vols. Venda Nova: Bertrand Editora. 
Galavís Bueno, F. (2010). Consideraciones sobre el Barrio Gótico de Valencia de Alcântara. Badajoz: edição de autor.

Gargallo Gil, J. E. (1999). Las hablas de San Martín de Trevejo, Eljas y Valverde del Fresno. Trilogía de los tres lugares. Estudios y documentos sobre "A Fala". Mérida: Editorial Regional de Extremadura, vol. 1.

Oliveira, J.; Pereira, S.; \& Parreira, J. (2007). Ibn Maruán - Revista Cultural do Concelho de Marvão, nº 14, Nova Carta Arqueológica do Concelho de Marvão. Lisboa: Edições Colibri, Câmara Municipal de Marvão. Isquerdo, A.; \& Krieger, M. G. (orgs.) (2004). As Ciências do Léxico - Lexicologia, Lexicografia, Terminologia, vol. II. Campo Grande: Editora U.F.M.S.

Lopes, D. (1921-22). Toponímia árabe de Portugal. Revista Lusitana, vol. 24.

- (1930). Alguns vocábulos arábico-portugueses de natureza religiosa, étnica e lexicológica. Revista da Universidade de Coimbra, XI.

Machado, J. P. (1952). Dicionário Etimológico da Língua Portuguesa: com a mais antiga documentação escrita e conhecida de muitos vocábulos estudados (2a edição). Lisboa: Livros Horizonte (1967).

—. (1991). Vocabulário Português de Origem Árabe. Lisboa: Editorial Notícias.

Madoz Ibáñez, P. (1845-1850). Diccionario geográfico estadístico histórico de España y sus posesiones de Ultramar, 16 vols. Madrid: Establecimiento tipográfico de P. Madoz y L. Sagasti.

Maia, C. A. (1977). Os falares fronteiriços do concelho do Sabugal e da vizinha região espanhola de Xálima e Alamedilla. Revista Portuguesa de Filologia, Suplemento IV.

Martín Galindo, J. (1999). A Fala de Xálima - O falar fronteirizo de Valverde, Eljas y San Martín de Trevejo. Cáceres: Junta de Extremadura.

Medina García, E. (2006). Orígenes históricos y ambigüedad de la frontera hispano-lusa (La Raya). Revista de Estudios Extremeños, LXII, 2, 713-724.

Navas Sánchez-Élez, M. V. (2000). Procesos de creación de las lenguas fronterizas. Revista de Filología Románica, 17, 367-393.

Ossenkop, C. (2006). La situación lingüística actual de las variedades portuguesas en la franja fronteriza de Valencia de Alcántara. Revista de Estudios Extremeños, LXII, 2, 661-681.

Rio-Torto, G. (1993). Formação de Palavras em Português. Aspectos da Construção de Avaliativos. Tese de doutoramento apresentada à Faculdade de Letras da Universidade de Coimbra. . (1998). Morfologia Derivacional - Teoria e Aplicação ao Português. Porto: Porto Editora.

- (2006). O Léxico: semântica e gramática das unidades lexicais. Coimbra: Faculdade de Letras da Universidade de Coimbra. Centro Interuniversitário de Estudos Germanísticos.

Salvador Plans, A.; Carrasco González, J.; \& García Oliva, M. (Coords.) (2000). Actas del Congreso sobre "A Fala". 20 y 21 de mayo de 1999. Eljas - San Martín de Trebejo - Valverde del Fresno. Mérida: Editora Regional de Extremadura y Gabinete de Iniciativas Transfronterizas de la Junta de Extremadura.

Sidarus, A. (1991). Amaia de Ibn Maruán: Marvão. Ibn Maruán - Revista Cultural do Concelho de Marvão, $\mathrm{n}^{\circ} 1,13-26$.

Simão, T. (2010). O Falar de Marvão. Dissertação de mestrado apresentada à Universidade de Évora.

. (2011). O Falar de Marvão - pronúncia, vocabulário, alcunhas, ditados e provérbios populares. Lisboa: Edições Colibri.

. (2015). O Falar de Marvão - Património Imaterial Raiano. Tese de doutoramento apresentada à Universidade de Évora. . (2016). Dicionário do Falar Raiano de Marvão. Lisboa: Edições Colibri. 
Sousa, J.; \& Moura, J. (2004). Vestigios da Lingoa Arabica em Portugal. Lisboa: Livraria Alcalá. (facsimile da edição de 1830)

Vargens, J. B. (1999). Arabismos na língua portuguesa (subsídios para um estudo do léxico português de origem árabe). Tese de doutoramento apresentada à Universidade de Lisboa.

Vasconcelos, J. L. (1890-1892). Dialectos Alentejanos. Revista Lusitana II, 15-45. . (1896). Dialectos Alemtejanos. Revista Lusitana IV, 13-77; 215-246. - (1897). Mapa dialectológico do Continente Português. Lisboa: Guillard, Aillaud \& Cia. . (1901). Esquisse d'une Dialectologie Portugaise (3. ${ }^{\mathrm{a} e d}$.) Lisboa: Instituto Nacional de Investigação Científica - Centro de Linguística da Universidade de Lisboa (1987). - (1929). Opúsculos - vol. IV Filologia. Coimbra: Imprensa da Universidade.

Vilela, M. (1995). Ensino da Língua Portuguesa: Léxico, Dicionário, Gramática. Coimbra: Almedina.

Villar, M. (Dir.) (2011). Dicionário do Português Atual Houaiss. 2 vols. Lisboa: Círculo de Leitores/ Sociedade Houaiss-Edições Culturais, Lda. 